\title{
FACTORS ASSOCIATED WITH EXCLUSIVE BREASTFEEDING: APPLICATION OF PRECEDE-PROCEED MODEL AND THEORY OF PLANNED BEHAVIOR
}

\author{
Anggityas Alfianrisa ${ }^{1)}$, Harsono Salimo ${ }^{2)}$ \\ Eti Poncorini Pamungkasari3) \\ 1)Masters Program in Public Heath, Sebelas Maret University \\ 2)Department of Pediatrics, Dr. Moewardi Hospital, Surakarta \\ 3) Faculty of Medicine, Sebelas Maret University
}

\begin{abstract}
Background: Exclusive breastfeeding (EBF) is an ideal food for infants aged o-6 months. EBF is useful for infants, but it is under-implemented. A non profit organization, namely Indonesian Association of Lactating Mothers (AIMI), has been established recently, with an objective to disseminate knowledge and information on breastfeeding and to increase breastfeeding practice in Indonesia. This study aimed to examine factors associated with exclusive breastfeeeding using PRECEDE-PROCEED model and Theory of Planned Behavior.
\end{abstract}

Subjects and Method: This was an analytic observational study with retrospective cohort design. This study was conducted at Pajang Community Health Center, Surakarta, Central Java, from January to March, 2017. A total sample of 20 lactating mothers were selected for this study by simple random sampling. The dependent variable was exclusive breastfeeding. The independent variables were maternal education, maternal employment status, participationin AIMI, knowledge, attitude, family support, perceived behavior control, and intention. The data were collected by a set of questionnaire and analyzed by path analysis.

Results: Exclusive breastfeeding were positively associated with maternal education $\geq$ senior high school $(b=-0.13 ; \mathrm{SE}=0.22 ; \mathrm{p}=0.572)$, participation in AIMI $(b=0.45, S E=0.26, p=0.085)$, maternal employment status $(b=-0.63$; $\mathrm{SE}=0.20 ; \mathrm{p}=0.002)$, attitude $(\mathrm{b}=0.05 ; \mathrm{SE}=0.03 ; \mathrm{p}=0.172)$, family support $(\mathrm{b}=0.06 ; \mathrm{SE}=0.03 ; \mathrm{p}=0.039)$, perceived behavior control $(\mathrm{b}=0.04 ; \mathrm{SE}=$ 0.03; $\mathrm{p}=0.164)$, and intention $(b=0.09 ; \mathrm{SE}=0.05 ; \mathrm{p}=0.045)$. EBF intention were positively associated with maternal education $\geq$ senior high school $(b=$ 1.44; $\mathrm{SE}=0.42 ; \mathrm{p}<0.001)$, participation in AIMI $(\mathrm{b}=0.55 ; \mathrm{SE}=0.46 ; \mathrm{p}=$ $0.229)$, attitude $(b=0.11 ; \mathrm{SE}=0.06 ; \mathrm{p}=0.046)$ and perceived behavior control $(\mathrm{b}=0.38 ; \mathrm{SE}=0.05 ; \mathrm{p}<0.001)$.

Conclusion: Exclusive breastfeeding are positively associated with maternal education $\geq$ senior high school, participation in AIMI, maternal employment status, attitude, family support, perceived behavior control, and intention. EBF intention are positively associated with maternal education $\geq$ senior high school, participation in AIMI, attitude and perceived behavior control.

Keywords: PRECEDE-PROCEED, theory of planned behavior, AIMI, exclusive breastfeeding

Correspondence: Anggityas Alfianrisa. Masters Program in Public Health, Sebelas Maret University, Jl. Ir. Sutami 36 A, Surakarta 57126, Central Java, Indonesia. Email: anggityasrisa@gmail.com. Mobile: +6285647563476. 